\title{
Expert System Diagnosing Diabetes Using the Web-Based Dempster Shafer Method
}

Siti Ilya Suwella, Fristi Riandari,

Informatics Engineering, STMIK Pelita Nusantara, Sumatera Utara, Indonesia

\section{Article Info}

\section{Article history:}

Received: 27/09/2021

Revised: 09/10/2021

Accepted: 07/11/2021

Available online 01/12/2021

\section{Keywords:}

Diabetes,

Dempster Shafer,

Expert System,

WEB.

\begin{abstract}
Diabetes is a very dangerous disease because diabetes can attack other organs of the body so that it can cause death. This is due to the lack of technology-based information that can help determine the symptoms of diabetes. With the limited number of diabetes experts, an expert system is needed to diagnose diabetes. The method applied to the system is the Dempster Shafer method, by determining 17 symptoms and 3 types of disease, as well as compiling a rule base in determining the relationship of each symptom so that the results in the calculation achieve $100 \%$ accurate results. This method has 5 steps in its completion. The results showed that the Dempster Shafer method could be used to diagnose the symptoms of diabetes. So that the existence of this system can help the wider community in finding information about the symptoms of diabetes.
\end{abstract}

This is an open access article under the CC BY-NC license.

\section{Corresponding Author:}

Fristi Riandari,

Informatics Engineering,

STMIK Pelita Nusantara Medan,

Jl Iskandar Muda No. 1 Medan, 20154, Indonesia.

Email: fristy.rianda@ymail.com

\section{Introduction}

Information technology is very important in the Industry 4.0 era, because in the Industry 4.0 era it is already based on information technology in all fields, one of which is technology. Technology has now entered the world of health. Due to the limitations of an expert in diagnosing a disease, a system is needed. This problem will be more appropriate if applied in the field of computer-based technology, namely the Expert System because it can help the community in diagnosing a disease easily without having to travel long distances to the hospital.

The Expert System for diagnosing diabetes is applied using the Dempster Shafer method, which is a method of proving the value of trust based on theoretical evidence (reasonable thinking) and a belief function that is used to explain the possibility in combination with separate information (evidence) that occurred at the time of the event [1].

One of the diseases that is feared and often occurs among adults is diabetes. Diabetes is a dangerous disease that is usually characterized by high blood sugar levels [2]. The main source of energy in the cells of the human body is called glucose or blood sugar. Glucose that has accumulated in the blood because it cannot be taken up by the body's cells when it is good can cause various disorders in the body's organs.

This study aims to determine how the application of the Expert System in diagnosing diabetes and to find out how the application of the Dempster Shafer method to produce information in diagnosing the symptoms of a disease experienced by the community. 
In a previous study in the journal [3] with the title In research related to the application of a webbased expert system to diagnose diabetes with the title expert system diagnosing diabetes using the certainty factor method by taking 3 types of diseases with 8 kinds of symptoms with different weights. [4]. In the same study with the Diabetes Mellitus Detection Expert System using the Forward chaining method and Android-based Certainty factor. This study uses 2 types of diabetes mellitus data with 11 symptoms of the disease [5]. Another study entitled Designing an Expert System to Diagnose Diabetes Mellitus Using the Certainty Factor Method in this study used 2 types of diseases with 15 symptoms of the disease [6]. His research entitled Expert System to Diagnose Diabetes Using the Certainty Factor Method in this study discusses 2 types of diseases with 9 types of symptoms of the disease [7]. Another study entitled Expert System Applications for Diagnosing Diabetes Mellitus with Web-Based Certainty Factor Algorithm in this study used 2 types of disease data [8].

\section{Method}

\subsection{Research Framework}

The stages of this research are carried out in order to solve the problems that will be discussed. This is done with the aim of collecting information related to the problems to be studied.

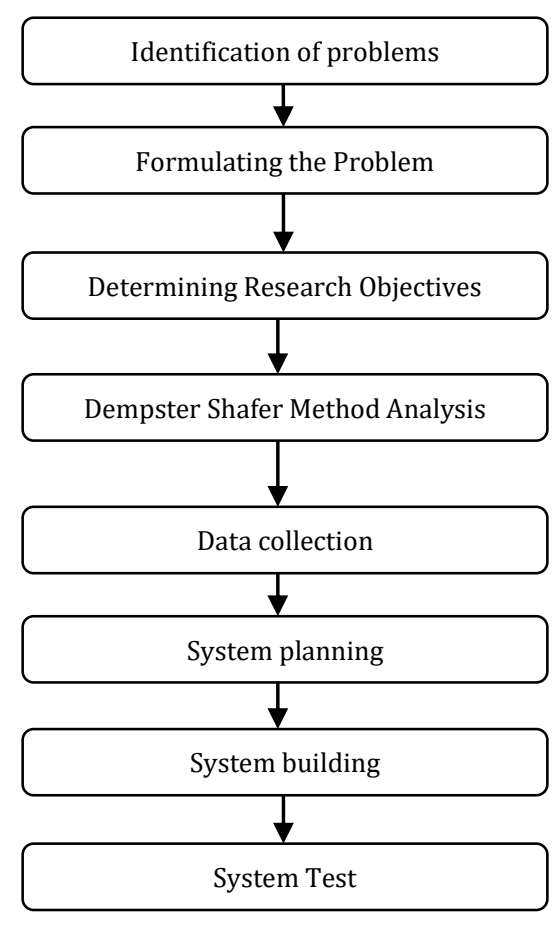

Figure1. Research Framework

\subsection{Description of the Framework}

The description of the framework is a further explanation regarding the description of the process of the research framework carried out, along with the explanation:

a. Problem Identification

Doing research around the problem to be discussed, in this study the data that will be used in the system to be built is in determining the symptoms of diabetes that will be used, as well as the relationship between each symptom in each disease.

b. Formulate the Problem

Formulating the problem is to find and choose what problems will be solved in this research.

c. Determine Research Objectives 
To develop problems that have been searched for so that it is easier to analyze methods in research.

d. Analysis of the Dempster Shafer Method

This step is to analyze all the data that is processed in the system or design process, the data to be input is 17 symptom data, 3 types of diabetes and their handling solutions which will be processed using the Dempster Shafer Method.

e. Data Collection

Data collection is done by using R\&D (Research And Development) technique.

1). Interview

In this case, the researcher conducted interviews with specialists in internal medicine at the Melati Perbaungan General Hospital. With dr. Arief Kurniawan Siregar, Sp.PD.

2). Observation This method is an on-site data collection. This process is carried out through observations, including recording, counting, measuring and recording events. Observations were carried out on Jl. Deli No.115, Simpang Tiga Pekan, Kec. Perbaungan, Serdang Bedagai Regency, North Sumatra 20986.

3). Literature review

4). In this case, the researcher uses several library sources including: Books, National Journals, Documentation, and other sources.

f. System Design

In system design is a step to create or establish something in the thought process that is thought as accurately as possible. The design in this study is the application of the Dempster Shafer method in diagnosing diabetes.

g. System Development

At this stage a system will be built using the sublimetext application as a web-based programming language with a database using sql with the XAMPP application so that a diabetes diagnosis web application is formed.

h. System Testing

Testing is a step where something that has been made will be tested, in order to minimize errors and ensure the output produced is as desired.

\section{Results and Discussion}

The following is data obtained from the Jasmine Perbaungan Hospital:

TABLE 1.

Data Obtained From The Jasmine Perbaungan Hospital

\begin{tabular}{|c|c|c|c|c|c|}
\hline Code & Symptom Name & $\begin{array}{c}\text { P1 } \\
\text { Diabetes } \\
\text { Tipe } 1\end{array}$ & $\begin{array}{c}\text { P2 } \\
\text { Diabetes } \\
\text { Tipe } 2\end{array}$ & $\begin{array}{c}\text { P3 } \\
\text { Diabetes } \\
\text { gestasional }\end{array}$ & $\begin{array}{c}\text { Probailit } \\
\text { as }\end{array}$ \\
\hline G1 & Often feel thirsty & $\sqrt{ }$ & $\sqrt{ }$ & $\sqrt{ }$ & 0.6 \\
\hline $\mathrm{G} 2$ & Frequent urination & $\sqrt{ }$ & $\sqrt{ }$ & $\sqrt{ }$ & 0.6 \\
\hline G3 & Often feel hungry & $\sqrt{ }$ & $\sqrt{ }$ & $\sqrt{ }$ & 0.6 \\
\hline G4 & Lose weight & $\sqrt{ }$ & $\sqrt{ }$ & & 0.8 \\
\hline G5 & $\begin{array}{l}\text { Decreased muscle } \\
\text { mass }\end{array}$ & $\sqrt{ }$ & $\sqrt{ }$ & & 0.8 \\
\hline G6 & Dry mouth & $\sqrt{ }$ & $\sqrt{ }$ & $\sqrt{ }$ & 0.4 \\
\hline G7 & Pain in the legs & $\sqrt{ }$ & $\sqrt{ }$ & & 0.8 \\
\hline G8 & Itchy rash & $\sqrt{ }$ & & & 0.4 \\
\hline G9 & $\begin{array}{l}\text { Erectile dysfunction } \\
\text { or impotence }\end{array}$ & $\sqrt{ }$ & & $\sqrt{ }$ & 0.5 \\
\hline G10 & Easily offended & & $\sqrt{ }$ & & 0.5 \\
\hline G11 & $\begin{array}{l}\text { Experiencing reactive } \\
\text { hypoglycemia }\end{array}$ & & $\sqrt{ }$ & $\sqrt{ }$ & 0.3 \\
\hline G12 & $\begin{array}{l}\text { The appearance of } \\
\text { black spots }\end{array}$ & & $\sqrt{ }$ & $\sqrt{ }$ & 0.2 \\
\hline
\end{tabular}




\begin{tabular}{|c|c|c|c|c|c|}
\hline Code & Symptom Name & $\begin{array}{c}\text { P1 } \\
\text { Diabetes } \\
\text { Tipe } 1 \\
\end{array}$ & $\begin{array}{c}\text { P2 } \\
\text { Diabetes } \\
\text { Tipe } 2 \\
\end{array}$ & $\begin{array}{c}\text { P3 } \\
\text { Diabetes } \\
\text { gestasional }\end{array}$ & $\begin{array}{c}\text { Probailit } \\
\text { as }\end{array}$ \\
\hline G13 & $\begin{array}{l}\text { There are ketones in } \\
\text { the urine }\end{array}$ & & $\sqrt{ }$ & $\sqrt{ }$ & 0.2 \\
\hline G14 & Weak & & & $\sqrt{ }$ & 0.5 \\
\hline G15 & Blurred vision & & & $\sqrt{ }$ & 0.4 \\
\hline G16 & $\begin{array}{l}\text { Wounds that are hard } \\
\text { to heal }\end{array}$ & & & $\sqrt{ }$ & 0.5 \\
\hline G17 & Frequent infections & & & $\sqrt{ }$ & 0.8 \\
\hline
\end{tabular}

\subsection{Case Examples}

A diabetic patient named Sumarni at the age of 38 years who experienced symptoms of frequent thirst, weight loss, and ketones in the urine. The calculation steps are as follows:

With the condition that:

a. Symptom 1 (often feeling thirsty) is in the rules of type 1 Diabetes \& Type 2 Diabetes \& Gestational Diabetes

b. Symptom 2 (Loss of weight) is in the rules for Type1 Diabetes \& Type2 Diabetes

c. Symptom 3 (There are ketones in the urine) is in the rules for Type 2 Diabetes \& Gestational Diabetes

Then determine the Initial Density with the following conditions:

a. Belief is the initial value (Probability)

b. Plausibility is 1 minus the initial value (Probability)

Determine the initial density, of the two selected symptoms by calculating symptom 1 and symptom 2 .

TABLE 2.

DETERMINE THE INITIAL DENSITY

\begin{tabular}{|c|c|c|c|c|}
\hline Densitas & Symptom & Disease & Belief & Plausibility \\
\hline M1 & $\begin{array}{l}\text { Often feel } \\
\text { thirsty }\end{array}$ & P1,P2,P3 & 0.6 & 0.4 \\
\hline M2 & Lose weight & $\mathrm{P} 1, \mathrm{P} 2$ & 0.8 & 0.2 \\
\hline
\end{tabular}

To facilitate the calculation, the subsets formed are entered into the table. So that the value of $\mathrm{m} 3$ is obtained as a result of the combination of $\mathrm{m} 1$ and $\mathrm{m} 2$. Perform a combination calculation by calculating the 1st symptom and 2 nd symptom.

TABLE 3.

Perform a combination Calculation by Calculating the 1st Symptom and 2nd Symptom

\begin{tabular}{ccc}
\hline & $\begin{array}{c}\mathrm{m}_{2}\{\mathrm{P} 1, \mathrm{P} 2\} \\
0.8\end{array}$ & $\begin{array}{c}\mathrm{m}_{2}\{\theta\} \\
0.2\end{array}$ \\
\hline $\begin{array}{c}1\{\mathrm{P} 1, \mathrm{P} 2, \mathrm{P} 3\} \\
0.6\end{array}$ & $\mathrm{P} 1, \mathrm{P} 2$ & $\mathrm{P} 1, \mathrm{P} 2, \mathrm{P} 3$ \\
$\mathrm{~m}_{1}\{\theta\}$ & 0.48 & 0.12 \\
0.4 & $\mathrm{P} 1, \mathrm{P} 2$ & $\theta$ \\
& 0.32 & 0.08
\end{tabular}

So it can be that:

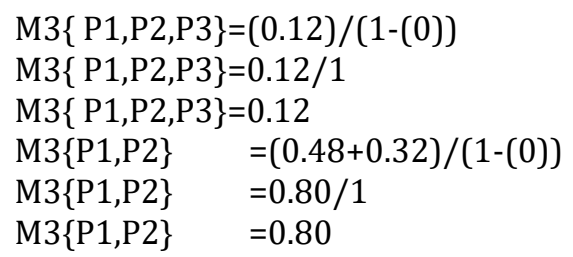


$\mathrm{M} 3\{\theta\}=0.08 /(1-(0))$

$\operatorname{M} 3\{\theta\}=0.08 / 1$

$\operatorname{M} 3\{\theta\}=0.08$

Then do the second combination to look for the third symptom.

Then combine the results of the initial density with the selected new symptoms and calculate the value of M3 with M4

TABLE 4

DENSITY CoMbinations (2)

\begin{tabular}{lllcc}
\hline Densitas & Symptom & Disease & Belief & Plausibility \\
\hline \multirow{2}{*}{ M3 } & Frequent thirst and & P1,P2,P3 & 0.12 & 0.08 \\
weight loss & P1,P2 & 0.80 & \multirow{2}{*}{ M4 } \\
$\begin{array}{l}\text { There are ketones } \\
\text { in the urine }\end{array}$ & P2,P3 & 0.2 & 0.8 \\
\hline
\end{tabular}

Then the combination is done again so that the following results are obtained:

Perform a combination calculation by counting 3 symptoms. The 1 st and 2 nd symptoms are calculated by combining the values of the 2 symptoms and calculated by the 2 nd symptom value.

TABLE 5.

Combine The Results Of The Initial Density With The Selected New Symptoms

\begin{tabular}{ccc} 
& $\mathrm{m}_{4}\{\mathrm{P} 2, \mathrm{P} 3\}$ & $\mathrm{m}_{4}\{\theta\}$ \\
& 0.2 & 0.8 \\
\hline $\mathrm{m}_{3}\{\mathrm{P} 1, \mathrm{P} 2, \mathrm{P} 3\}$ & $\mathrm{P} 2, \mathrm{P} 3$ & $\mathrm{P} 1, \mathrm{P} 2, \mathrm{P} 3$ \\
0.12 & 0.024 & 0.096 \\
$\mathrm{~m}_{3}\{\mathrm{P} 1, \mathrm{P} 2\}$ & $\mathrm{P} 2$ & $\mathrm{P} 1, \mathrm{P} 2$ \\
0.80 & 0.16 & 0.64 \\
$\mathrm{~m}_{3}\{\theta\}$ & $\mathrm{P} 2, \mathrm{P} 3$ & $\theta$ \\
0.08 & 0.016 & 0.064 \\
\hline
\end{tabular}

So it can be that:

\begin{tabular}{|c|c|}
\hline $\mathrm{M} 5\{\mathrm{P} 1, \mathrm{P} 2, \mathrm{P} 3\}$ & $=(0.096) /(1-(0))$ \\
\hline $\mathrm{M} 5\{\mathrm{P} 1, \mathrm{P} 2, \mathrm{P} 3\}$ & $=0.096 / 1$ \\
\hline $\mathrm{M} 5\{\mathrm{P} 1, \mathrm{P} 2, \mathrm{P} 3\}$ & $=0.096^{\prime}$ \\
\hline $\mathrm{M} 5\{\mathrm{P} 1, \mathrm{P} 2\}$ & $=(0.64) /(1-(0))$ \\
\hline $\mathrm{M} 5\{\mathrm{P} 1, \mathrm{P} 2\}$ & $=0.64 / 1$ \\
\hline $\mathrm{M} 5\{\mathrm{P} 1, \mathrm{P} 2\}$ & $=0.64^{\prime}$ \\
\hline $\mathrm{M} 5\{\mathrm{P} 2, \mathrm{P} 3\}$ & $=(0.024+0.016) /(1-(0))$ \\
\hline $\mathrm{M} 5\{\mathrm{P} 2, \mathrm{P} 3\}$ & $=0.040 / 1$ \\
\hline $\mathrm{M} 5\{\mathrm{P} 2, \mathrm{P} 3\}$ & $=0.040$ \\
\hline M5\{P2\} & $=(0.16) /(1-(0))$ \\
\hline M5\{P2\} & $=0.16 / 1$ \\
\hline M5\{P2\} & $=0.16$ \\
\hline $\operatorname{M5}\{\theta\}$ & $=(0.064) /(1-(0))$ \\
\hline $\operatorname{M5}\{\theta\}$ & $=0.064 / 1$ \\
\hline $\operatorname{M5}\{\theta\}$ & $=0.064$ \\
\hline
\end{tabular}

\subsection{System Design and Implementation}

a. Use Case Diagrams

In this use case, know what functions exist in the system that is made. The use case diagram for diagnosing diabetes is shown below: 


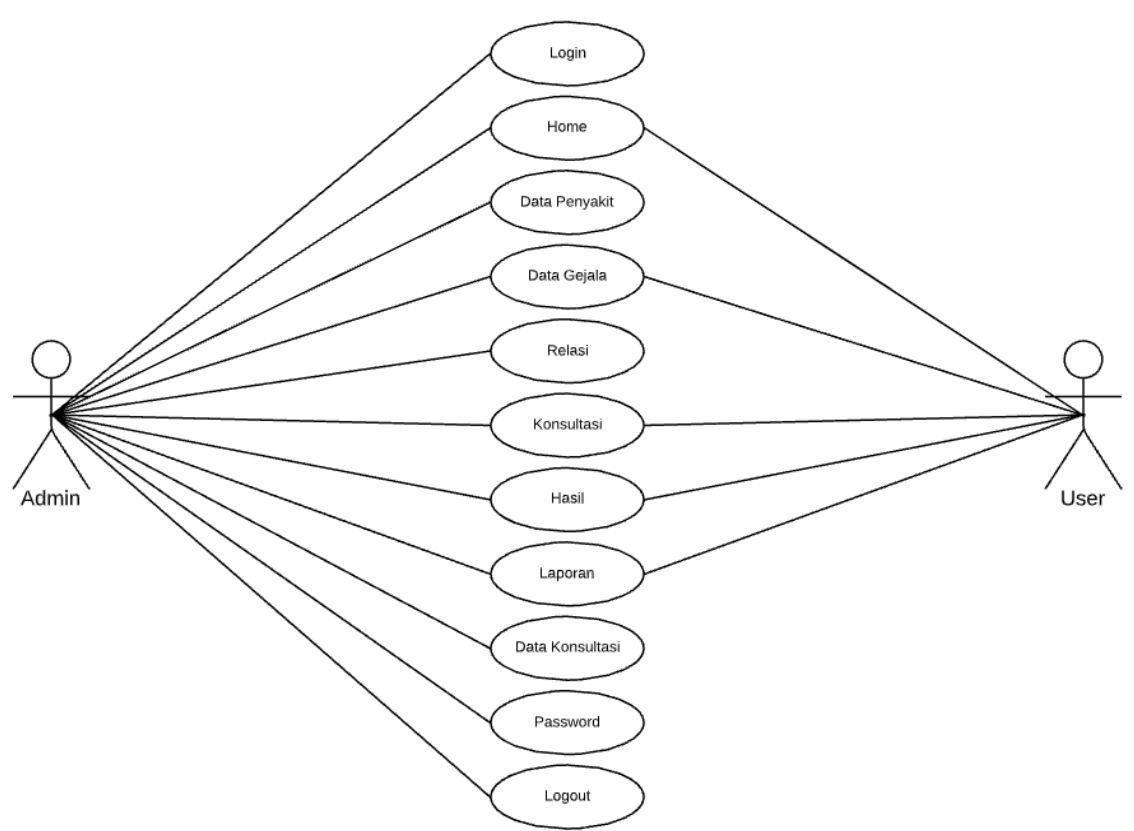

Figure2. Use Case Diagram

After implementing the Dempster Shafer method, a system is implemented that serves to present the program results from expert system research to diagnose diabetes using the Dempster Shafer method. The output display is a display of the results of the Dempster Shafer process. The following displays the output page of the previously inputted data.

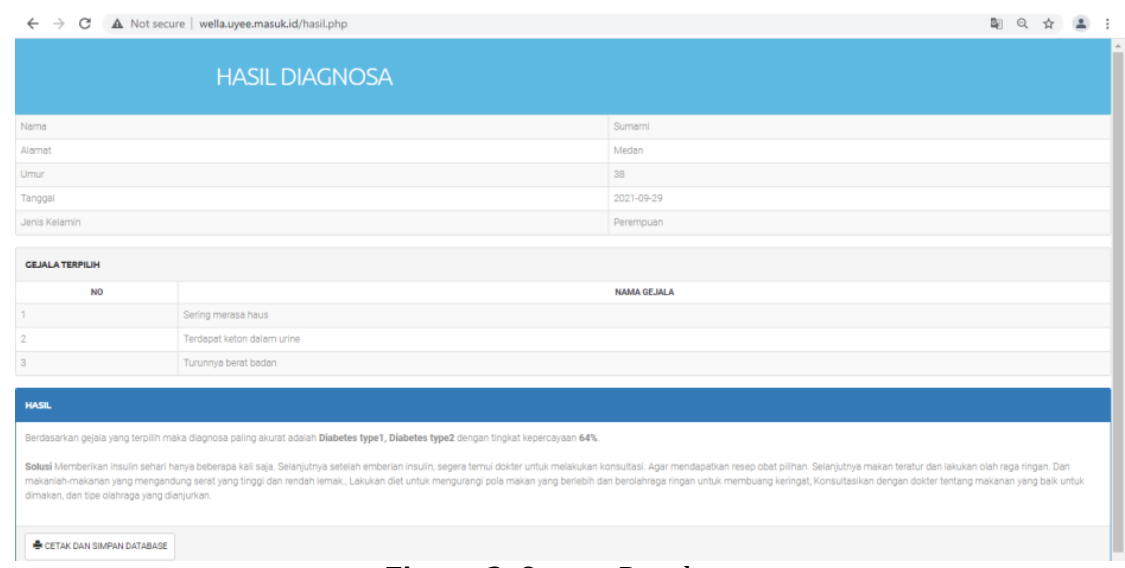

Figure 3. Output Result

After getting the value results from the calculation of diabetes symptoms above, then the results of the hypothesis based on the inputted symptoms, which get the largest value is M5 with a value of 0.64. So M5 can be written as P1 and P2 or Diabetes type 1 and Diabetes type 2 with a percentage value of $64 \%$.

Of the three symptoms, Sumarni's frequent thirst, weight loss, and presence of ketones in the urine were evaluated using the Dempster Shafer expert system. So it can be concluded that sumarni may be affected by type 2 diabetes with a value of $64 \%$. 


\section{Conclusion}

Based on the previous discussion and discussion, the conclusion is to design an application with a web-based diabetes diagnosis expert using the help of a sublime text application because in making PHP and CSS coding done helps accelerate the development of this program and build a database using sql with XAMPP the application also helps in data storage . Building an expert system in diagnosing diabetes is very helpful for the community, especially in early detection of diabetes in adults which usually will appear gradually, it can take months to years ignored or ignored.

\section{Referensi}

[1] R. Setiawan, C. Suhery, and S. Bahri, "Implementasi Metode Dempster Shafer Pada Sistem Pakar Diagnosa Infeksi Penyakit Tropis Berbasis Web," J. Coding, vol. 06, no. 03, pp. 97-106, 2018.

[2] S. Hardani, "Diagnosa Penyakit Diabetes Dengan Metode Forward Chaining," JITK (Jurnal Ilmu Pengetah. dan Teknol. Komputer), vol. 5, no. 2, pp. 231-236, 2020, doi: 10.33480/jitk.v5i2.1132.

[3] A. Prameshwari and N. P. Sastra, "Implementasi Algoritma Advanced Encryption Standard (AES) 128 Untuk Enkripsi dan Dekripsi File Dokumen," Eksplora Inform., vol. 8, no. 1, p. 52, 2018, doi: 10.30864/eksplora.v8i1.139.

[4] H. Khair, "Jurnal Teknik, Kesehatan dan Ilmu SISTEM PAKAR MENDIAGNOSA PENYAKIT DIABETES DENGAN Jurnal Teknik, Kesehatan dan Ilmu Sosial," vol. 1, no. 1, pp. 107-113, 2019.

[5] Y. P. Utami, A. Triayudi, and E. T. Esthi Handayani, "Sistem Pakar Deteksi Penyakit Diabetes Mellitus (DM) menggunakan Metode Forward chaining dan Certainty factor Berbasis Android," J. JTIK (Jurnal Teknol. Inf. dan Komunikasi), vol. 4, no. 2, p. 49, 2021, doi: 10.35870/jtik.v5i1.200.

[6] M. G. Pradana, B. W. Pamekas, and K. Kusrini, "Perancangan Sistem Pakar Untuk Mendiagnosa Penyakit Diabetes Mellitus Menggunakan Metode Certainty Factor Design Expert System for Diagnosing Diabetes Mellitus Using Certainty Factor Method," CCIT J., vol. 11, no. 2, pp. 182-191, 2018, doi: 10.33050/ccit.v11i2.586.

[7] J. Sistem and I. Kaputama, “2) 1,2,” vol. 4, no. 1, pp. 35-43, 2020.

[8] R. N. Putri and L. Goeirmanto, "Aplikasi Sistem Pakar Untuk Diagnosa Penyakit Diabetes Melitus," J. Apl. dan Inov. IPTEKS SOLIDITAS, vol. 3, pp. 106-112, 2020.

[9] D. Maharani, Salamun, Y. Arliando, and V. N. Sari, "Sistem Pakar Diagnosa Penyakit Diabetes Nefropathy Menggunakan Metode Certainty Factor," J. Inform. Polinema, vol. 1, no. 1, p. 65, 2018.

[10] S. Bacin, "Sistem Pakar Untuk Mendiagnosa Penyakit Diabetes Menggunakan Metode Inferensi Fuzzy Mamdani," vol. 1, no. 3, pp. 188-194, 2021, [Online]. Available: https://djournals.com/resolusi.

[11] K. Kirman, A. Saputra, and J. Sukmana, "Sistem Pakar Untuk Mendiagnosis Penyakit Lambung Dan Penanganannya Menggunakan Metode Dempster Shafer," Pseudocode, vol. 6, no. 1, pp. 58-66, 2019, doi: 10.33369/pseudocodse.6.1.58-66. 